\title{
SISTEM INFORMASI PENJUALAN KREDIT PADA MOHAN GROSIR SOLO SECARA MULTIUSER
}

\author{
Riwi Astuti ${ }^{1)}$, Bebas Widada ${ }^{2)}$, Andriani Kusumaningrum ${ }^{3)}$ \\ ${ }^{1,2,3)}$ Program Studi Sistem Informasi, STMIK Sinar Nusantara Surakarta \\ ${ }^{1)}$ riwiastuti@ gmail.com, ${ }^{2}$ bbswdd@yahoo.com, ${ }^{3)}$ andrianikkw@yahoo.com
}

\begin{abstract}
Mohan Grosir Solo is a store engaged in the field of Sales and Sales Cooperation Sales with Credit Sales System. Sales of credit that runs from direct submission to the cashier by submitting identity cards only. Customers do the taking of goods in accordance with the value of the approved filing then the customer will pay in accordance with the applicable provisions. With the credit sales information system is expected small errors up to the large can be resolved, especially the problem of payment arrears and repayment payment. System design that includes: Diagram Context, HIPO, Data Flow Diagrams, Document Flow Diagrams, Database Design, Input Design, Output Design, Implementation of the program by using appropriate data stimulation. The purpose of this research is to create and design multi-level loan sales information system at Mohan Grosir Solo. Then the results obtained from this system are Input of Goods Data, Input of Customer Data, Input of Supplier Data, Input of Data of Department of Goods, Input of Cashier Data, Purchase Transaction, Purchase Return Transaction, Credit Sale Transaction, Sales Return Transaction, Cash Transaction, Customer Data Report, Supplier Data Report, Department of Goods Data Report, Cashier Data Report, Purchase Transaction Report, Purchase Return Report, Credit Sales Transaction Report, Sales Returns Report, and Cash Advance Report. System information created using Microsoft Visual Basic 6 and SQL Server database has been done blackbox testing with a design that is appropriate.
\end{abstract}

Keywords: Information System, Multiuser, Credit Sales.

\section{PENDAHULUAN}

Kendala yang dialami Mohan Grosir antara lain, dalam transaksi masih sering terjadi kesalahan dalam perhitungan administrasi angsuran dan pelunasan. Selain itu, pencarian data mengalami error data karena terlalu banyaknya pelanggan yang sering terlambat mengangsur, maka dibuatlah rancangan penjualan kredit kepada konsumen dalam berbelanja dengan didukung perangkat aplikasi sebagai fasilitas layanan informasi yang memadai. Karena pelayanan yang baik dengan fasilitas-faslitas yang memadai sangat penting untuk kepuasan belanja para konsumen. Pembuatan sistem aplikasi penjualan kredit yang dapat membantu konsumen dalam pemenuhan kebutuhan gudang, kasir dan administrasi dalam menanggulangi keterlambatan angsuran dan update kredit dapat terprogram dengan baik. Dengan adanya sistem informasi penjualan kredit yang penulis buat diharapkan kesalahan yang kecil sampai dengan yang besar dapat teratasi.

\section{TINJAUAN PUSTAKA}

Sistem adalah kumpulan dari elemen-elemen yang berinteraksi untuk mencapai suatu tujuan tertentu (Muhammad Salahuddin, 2011).

Informasi ibarat darah yang mengalir di dalam tubuh manusia, maksud dari kalimat tersebut yaitu bahwa informasi sangat penting pada suatu organisasi. 
Informasi (information). Menurut Gordon B. Davis, informasi adalah data yang telah diproses ke dalam suatu bentuk yang dan terasa bagi keputusan saat itu atau keputusan mendatang (Sutabri.T, 2012)

Microsoft SQL Server adalah sebuah sistem manajemen basis data relasional (RDBMS) produk microsoft. Bahasa query utamanya adalah Transact-SQL yang merupakan implementasi dari SQL standar ANSI/ISO yang digunakan oleh Micosoft dan Sybase. Umumnya SQL Server digunakan di dunia bisnis yang memiliki basis data berskala kecil sampai dengan menengah tetapi kemudian berkembang dengan digunakannya SQL Server pada basis data besar (Wahana, 2010).

Penjualan Kredit adalah penyerahan barang, jasa, dari satu pihak (kreditor / penjualan) atas dasar kepercayaan kepada pihak lain (nasabah atau pengutang/borrower) dengan janji membayar dari penerima kredit kepada pemberi kredit pada tanggal yang telah disepakati kedua belah pihak (Rivai, 2013).

\section{METODE PENELITIAN}

Metode penelitian sangat diperlukan untuk kesempurnaan sistem yang penulis akan buat. Diperlukan metode-metode penelitian agar diperoleh data yang tepat dan akurat, diantaranya adalah :

\subsection{Metode Pengumpulan Data}

Pengumpulan data dibagi menjadi :

1. Metode Observasi

Metode observasi adalah pengamatan langsung terhadap suatu kegiatan yang sedang berlangsung atau mengetahui proses-proses yang terjadi dalam sistem informasi di Mohan Grosir. Hasil yang diperoleh yaitu berupa prosedur-prosedur dan persyaratan dalam mengajukan kredit.

2. Metode Wawancara

Metode tersebut memungkinkan penulis untuk mengumpulkan data secara bertatap muka dengan pimpinan sebagai orang yang diwawancarai mengenai hal-hal yang berhubungan dengan data penjualan kredit di Mohan Grosir, sejarah berdirinya perusahaan, struktur organisasi dan tugas-tugasnya. Dengan metode ini penulis memperoleh data yang lebih akurat dan lengkap serta mempunyai nilai kebenaran.

3. Metode Kepustakaan

Metode ini merupakan cara yang ditempuh guna mengumpulkan data dan informasi serta pengetahuan yang berasal dari buku pedoman, referensi, maupun browsing internet yang berkaitan dengan topik permasalahan. Data yang diperoleh yaitu berupa teori-teori dasar mengenai pengertian tentang Sistem, Informasi, Multiuser, SQL Server, Visual Basic 6.0, Basis Data, Penjualan, Kredit, Grosir, dan Crystal Report.

\subsection{Perancangan Sistem}

\section{a. Analisis Sistem}

Adapun tahapan analisis sistem yaitu sebagai berkut:

1. Data Flow Diagram Context Level (Context Diagram)

Context Diagram adalah kasus khusus dari Data Flow Diagram (DFD) yang berfungsi untuk memetakan model lingkaran yang direpresentasikan dengan lingkaran tunggal yang mewakili keseluruhan sistem.

\section{Data Flow Diagram}

Data Flow Diagram adalah gambaran sistem secara logikal. Gambaran ini tidak tergantung pada perangkat keras, perangkat lunak, struktur data atau organisasi file. 


\section{HIPO}

HIPO (Hierarchy Plus Input Process Output) alat desain dan tehnik dokumentasi dalam siklus perkembangan sistem dari top level sistem utama sampai level 1 percabangan dari input, proses dan output.

4. Entity Relationship Diagram

ERD merupakan suatu model untuk menjelaskan hubungan antar data dalam basis data berdasarkan objek-objek dasar data yang mempunyai hubungan antar relasi.

\section{b. Desain Sistem}

Desain atau perancangan dalam pembangunan perangkat lunak merupakan upaya untuk mengonstruksi sebuah sistem yang memberikan kepuasan akan spesifikasi kebutuhan fungsional, memenuhi target, memenuhi kebutuhan secara implisit atau eksplisit dari segi performansi maupun penggunaan sumber daya, kepuasan batasan pada proses desain dari segi biaya, waktu dan perangkat.

1. Desain Input

Membahas tentang input tidak terlepas dari alat-alat input (input device) yang akan digunakan, misalnya keyboard, card reader dan lain-lain.

2. Desain Output

Output adalah produk dari sistem informasi yang dapat berupa hasil media kertas, hasil media lunak dan hasil dari suatu proses yang akan digunakan oleh proses lain yang tersimpan pada suatu media seperti tape, disk atau kartu. Sedangkan output yang dimaksud dalam desain ini adalah output yang berupa tampilan di media kertas atau di layar video.

3. Desain Database

Basis data (database) merupakan kumpulan dari data yang saling berhubungan satu dengan yang lainnya, tersimpan di simpanan luar komputer dan digunakan perangkat lunak tertentu untuk memanipulasinya.

\section{c. Implementasi Sistem}

Program yang sudah siap dilakukan dalam tahap perancangan maka proses selanjutnya adalah implementasi sistem. Sistem beserta program yang telah selesai dirancang tersebut diusahakan bisa dipahami dan mudah dimengerti oleh calon pengguna.

\section{d. Pengujian Sistem}

Pengujian yang dilakukan yaitu pengujian black box. Dimana pengujian black box berfokus pada persyaratan fungsional perangkat lunak yang dibuat tanpa menguji desain dan kode program. Pengujian dimaksudkan untuk mengetahui apakah fungsifungsi, masukan dan keluaran dari perangkat lunak sesuai dengan spesifikasi yang dibutuhkan.

\section{HASIL DAN PEMBAHASAN}

\subsection{Analisa Sistem}

Dalam tahap ini penulis menguraikan kebutuhan akan perangkat keras dan perangkat lunak yang digunakan dalam proses perancangan sistem informasi.

\subsection{Desain Sistem}

\section{a. Diagram Konteks}

Dalam kasus sistem informasi penjualan kredit dapat diterangkan pada Gambar 1 . 


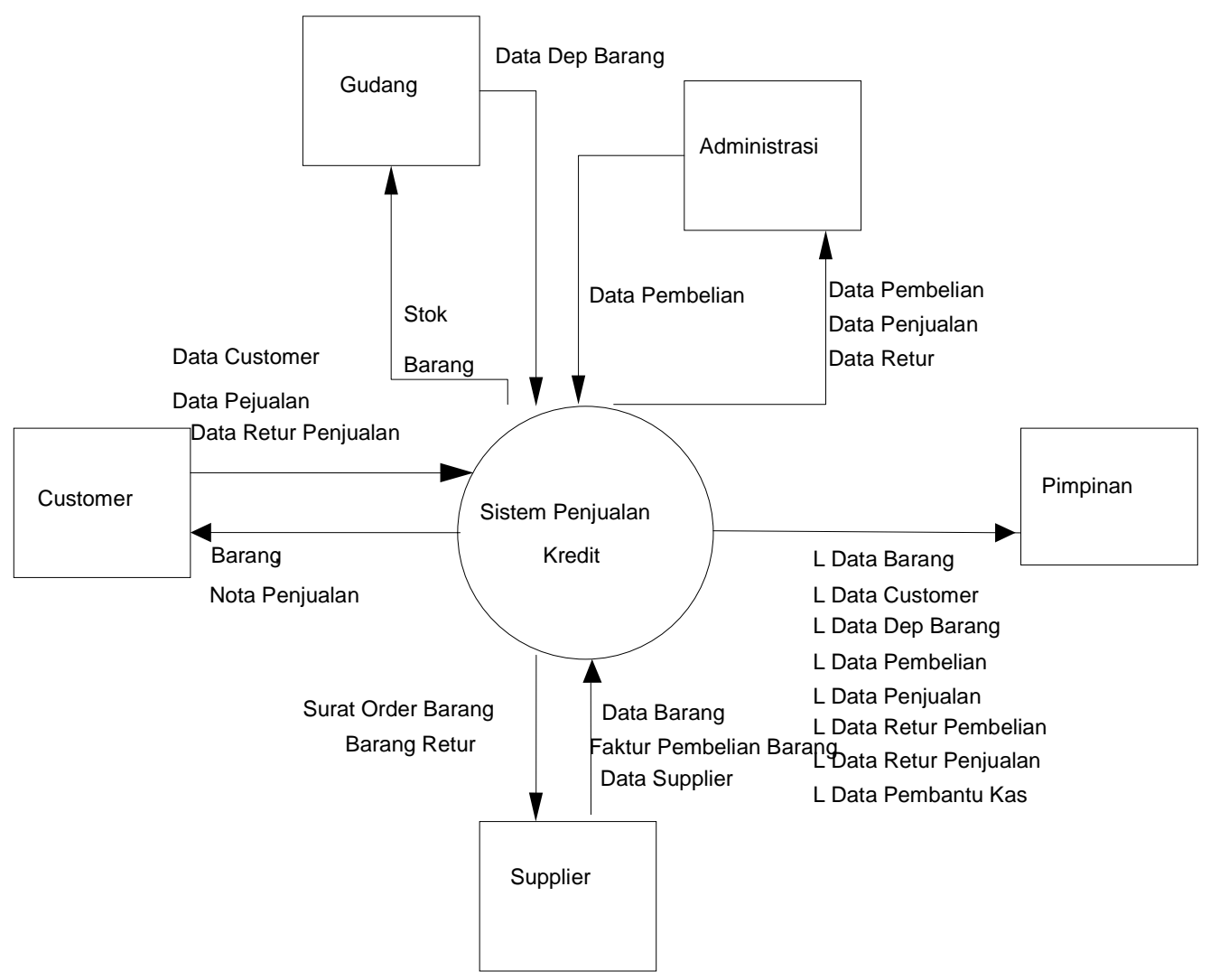

Gambar 1 Diagram Konteks

\section{b. HIPO}

HIPO digunakan sebagai alat desain dan teknik dokumentasi dalam siklus pengembangan. Sistem HIPO berbasis pada fungsi yaitu tiap-tiap modul dalam sistem digambarkan oleh fungsi utamanya. HIPO disajikan dalam bagan alir sistem dan struktur menu yang digunakan, seperti pada Gambar 2.

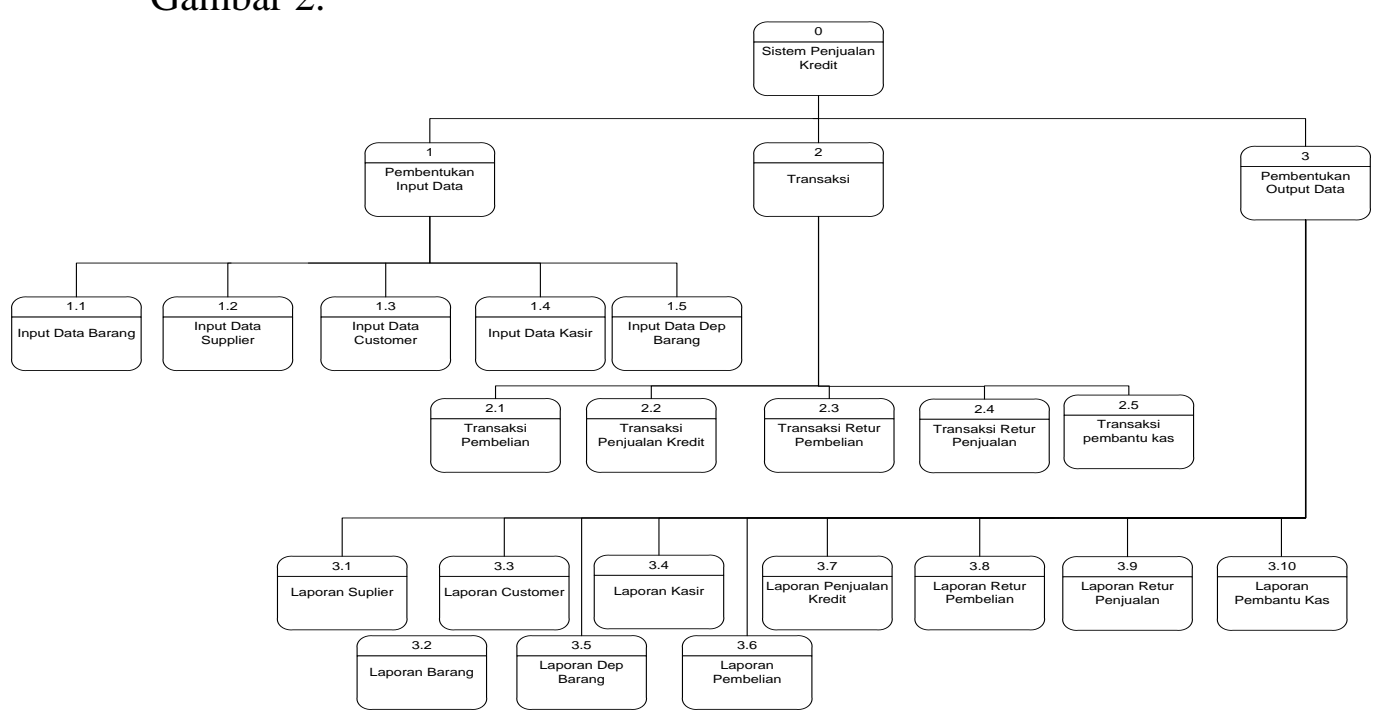

Gambar 2. HIPO

\section{c. Diagram Arus Data (DAD)}

Diagram Arus Data level 0 seperti pada Gambar 3, merupakan diagram penjabaran dari diagram konteks dan HIPO, tetapi pada Diagram Arus Data ini lebih 
mengarah pada suatu proses secara keseluruhan yang melibatkan semua kesatuan luar secara lengkap.

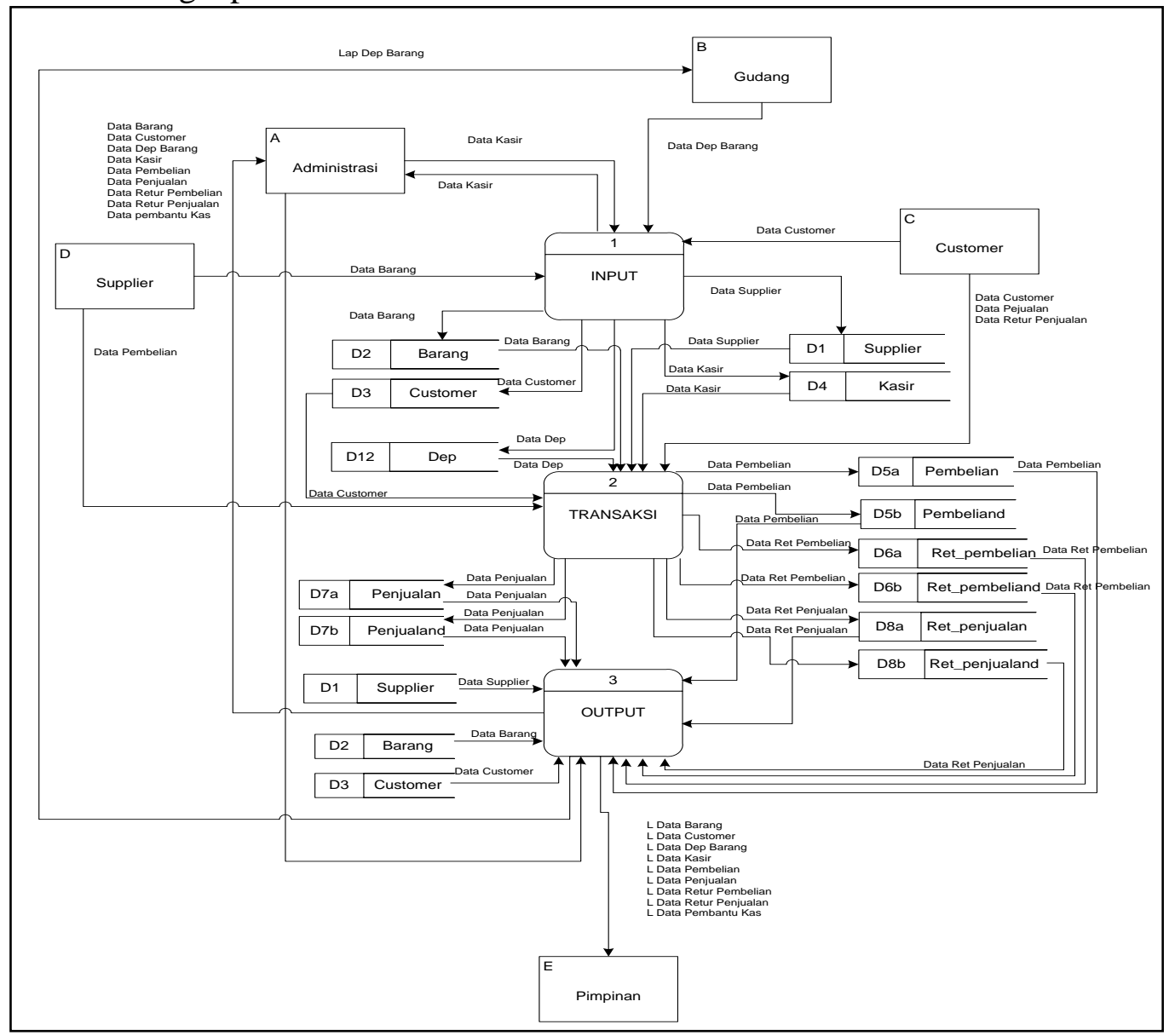

\section{d. Desain ERD}

Gambar 3 DAD

Dalam kasus sistem informasi penjualan kredit dapat diterangkan pada Gambar 4.

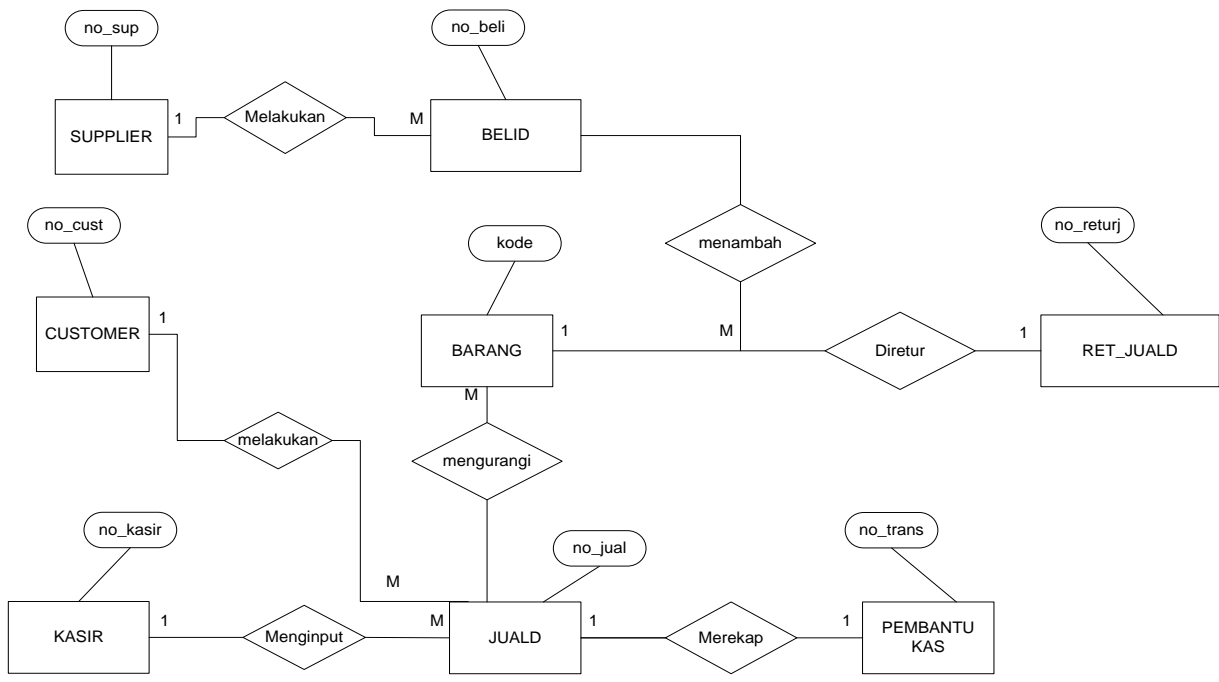

Gambar 4. ERD

Keterangan Gambar :

1. Satu supplier melakukan banyak proses beli, sehingga kardinalitasnya one to many. 
2. Satu customer melakukan banyak proses jual, sehingga kardinalitasnya one to many.

3. Satu kasir dapat menginput banyak proses jual, sehingga kardinalitasnya one to many.

4. Banyak proses beli dapat menambah satu barang, sehingga kardinalitasnya many to one.

5. Satu barang retur dapat diretur satu kali proses retur, sehingga kardinalitasnya one to one.

6. Banyak proses jual dapat mengurangi satu barang, sehingga kardinalitasnya many to one.

7. Satu proses jual dapat merekap satu proses pembantu kas, sehingga kardinalitasnya one to one.

\subsection{Implementasi Sistem}

Cara menjalankan program aplikasi ini dapat dilakukan dengan banyak cara. Menggunakan File Ext. Exe yaitu .exe (d: Iretaillretail.exe) atau buka file retaill.vbp dari visual basic dan jalankan menu run klik start. Dalam menu utama pengguna diberi hak untuk dapat mengganti tanggal sistem, dan jam sistem dengan cara klik text tanggal atau text jam (penggantian tanggal atau jam akan berakibat perubahan pada tanggal atau jam sistem komputer), sebelum masuk ke sistem menu utama anda akan langsung masuk ke sistem login masukkan nama user dan password, jika anda kasir akan ditampilkan shift yang anda jalankan.

a. Input Data Customer

Input data Customer seperti pada Gambar 5, dapat dimulai dengan klik Menu File klik Customer, untuk memulai input data tekan enter $(\triangleleft)$, atau klik ADD. Kode Customer otomatis terisi dan kursor mengarah ke nama, input data secara lengkap, setelah selesai klik SAVE. Jika ingin melakukan editing data dapat langsung edit dan simpan klik Save SAVE, panggil kode Customer yang akan dikoreksi, lakukan koreksi data dan jika selesai klik SAVE. Untuk menghapus klik DELETE maka akan muncul pesan Betul Akan Dihapus, jika OK maka data akan terhapus, Jika Cancel maka penghapusan akan dibatalkan. klik CLOSE untuk mengakhiri.

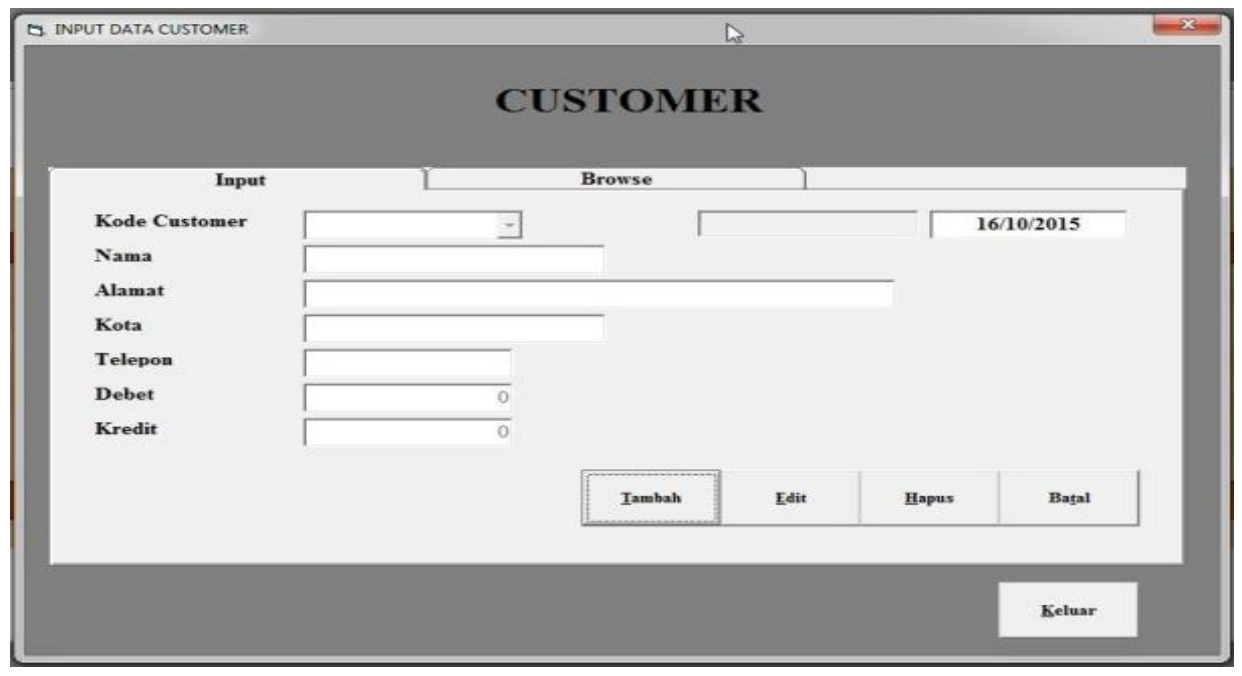

Gambar 5. Data Customer 


\section{b. Input Data Barang}

Input Data Barang seperti pada Gambar 6, dapat dimulai dengan klik Menu File klik barang. Untuk memulai input data tekan enter $(\downarrow)$ atau klik ADD, kode barang secara otomatis terisi dan kursor mengarah ke nama barang. Input data secara lengkap, setelah selesai klik SAVE. Jika ingin melakukan editing data dapat langsung edit dan simpan klik SAVE, panggil kode barang yang akan dikoreksi, lakukan koreksi data dan jika selesai klik SAVE. Untuk menghapus klik DELETE, klik CLOSE untuk mengakhiri

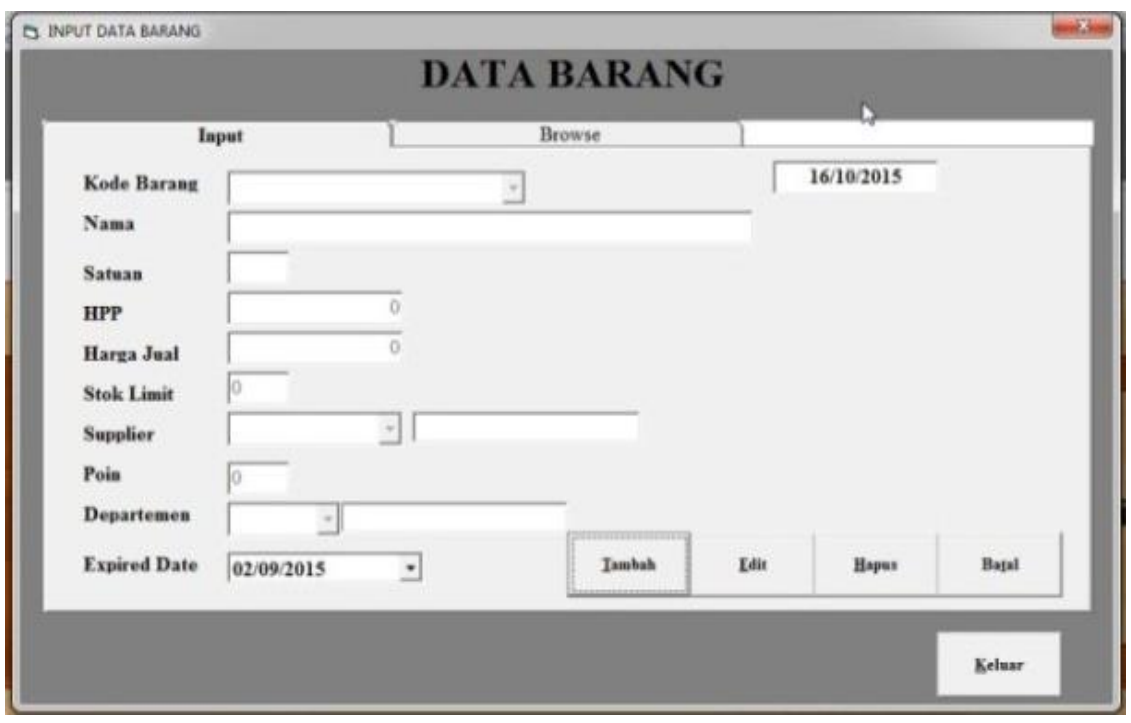

Gambar 6. Input Data Barang

c. Transaksi penjualan kredit

Transaksi penjualan kredit seperti pada Gambar 7, dapat dimulai dengan klik menu transaksi, Penjualan klik Penjualan atau bagi kasir langsung masuk dengan menggunakan login kasir. Untuk memulai input data tekan enter $(\downarrow)$ atau klik ADD, nomor penjualan retail secara otomatis terisi dan kursor mengarah ke no customer.. Lanjutkan input transaksi secara lengkap, setelah selesai klik SAVE. klik CLOSE untuk mengakhiri

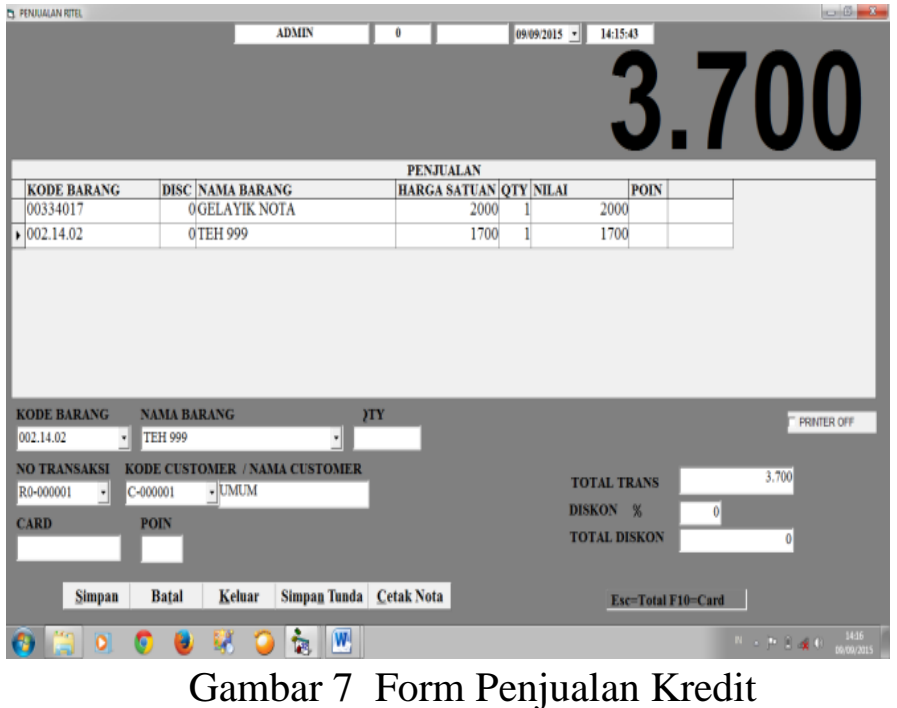

Gambar 7 Form Penjualan Kredit 
d. Transaksi pembantu kas

Transaksi pembantu kas seperti pada Gambar 8, dapat dimulai dengan klik menu transaksi, Pembantu Kas. Anda tinggal mengarahkan kemana anda mau melakukan pencarian. Klik CLOSE untuk mengakhiri.

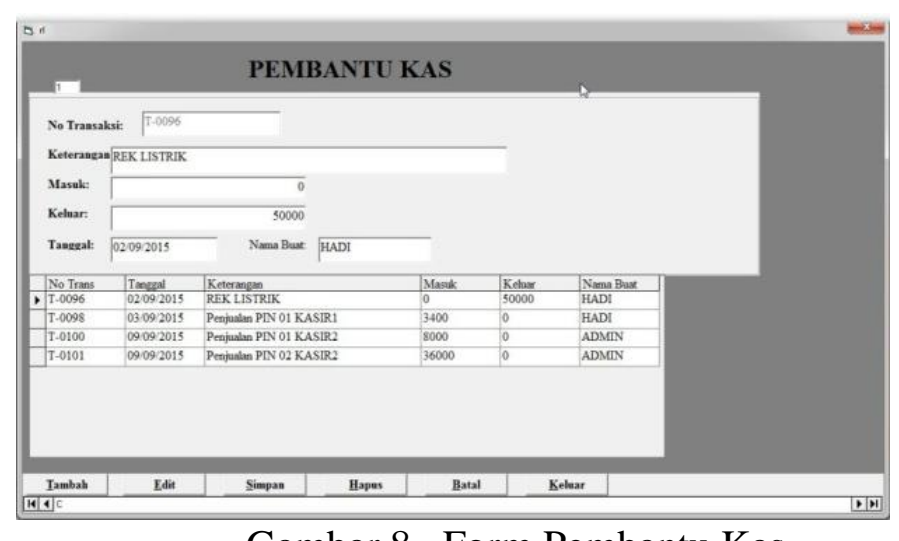

Gambar 8. Form Pembantu Kas

\section{e. Laporan}

Laporan dapat dilihat pada menu report, klik report klik laporan yang akan ditampilkan.

Untuk mencetak ke printer klik icon printer (昌) dan icon close (X) untuk mengakhiri. Laporan yang dihasilkan adalah :

- Laporan data customer

- Laporan data barang

- Laporan data Supplier

- Laporan data Kasir

- Laporan Pembelian

- Laporan transaksi penjualan kredit

- Laporan retur pembelian dan penjualan

- Laporan pembantu kas

\subsection{Pengujian Sistem}

Berikut initabel pengujian blackbox berdasarkan kasus pengujian pada aplikasi yang telah dibuat seperti pada Tabel 1,2 dan 3.

Tabel 1. Pengujian Fungsional Data Barang

\begin{tabular}{|c|c|c|c|c|}
\hline $\begin{array}{l}\text { Test } \\
\text { Case }\end{array}$ & Input Data & Target & Output Nyata & Sesuai \\
\hline 1 & $\begin{array}{l}\text { Kode barang :menggunakan } \\
\text { barcode pada kemasan. } \\
\text { Nama barang : Gatsby Musky } \\
\text { Sat : Pcs } \\
\text { dep : } 001 \\
\text { Harga Pokok : } 9325 \\
\text { Harga Penjualan : } 9700 \\
\text { Supplier:UD Salam Group } \\
\text { Exp : 11/12/2015 }\end{array}$ & $\begin{array}{l}\text { Simpan Data } \\
\text { Data tersimpan }\end{array}$ & $\begin{array}{l}\text { Data } \\
\text { Dikosongkan } \\
\text { Simpan } \\
\text { Berhasil } \\
\\
\text { DataTidak } \\
\quad \text { Tersimpan }\end{array}$ & Tidak Sesuai \\
\hline
\end{tabular}


Tabel 2 Pengujian Fungsional Customer

\begin{tabular}{|c|c|c|c|c|}
\hline Test Case & Input Data & Target & Output Nyata & Sesuai \\
\hline 1 & $\begin{array}{l}\text { Kode customer: C- } \\
00002 \\
\text { Nama customer: Toko } \\
\text { Feri } \\
\text { Alamat Customer: } \\
\quad \text { kartasura } \\
\text { Kota:solo } \\
\text { Telepon:0271-766510 } \\
\text { Debet : } 200000 \\
\text { Kredit : } 0\end{array}$ & $\begin{array}{l}\text { Hasil } \\
\text { Simpan Data } \\
\text { Data tersimpan }\end{array}$ & $\begin{array}{l}\text { Data } \\
\text { Dikosongkan } \\
\text { Simpan } \\
\text { Berhasil } \\
\\
\text { Hasil Tidak } \\
\quad \text { Keluar } \\
\text { Tidak } \\
\quad \text { Tersimpan }\end{array}$ & $\begin{array}{l}\text { Tidak } \\
\quad \text { Sesuai }\end{array}$ \\
\hline
\end{tabular}

Tabel 3 Pengujian Fungsional Penjualan Kredit

\begin{tabular}{|c|c|c|c|c|}
\hline Test Case & Input Data & Target & Output Nyata & Sesuai \\
\hline 1 & $\begin{array}{l}\text { Kode barang: } \\
\text { barcode } \\
\text { Nama barang: } \\
\text { Gatsby Musky } 175 \\
\text { Qty : 2 } \\
\text { Harga satuan: } 9700 \\
\text { Disc: 0 } \\
\text { Nilai : 0 } \\
\text { Poin : 0 } \\
\text { Total: } 19400\end{array}$ & $\begin{array}{l}\text { Hasil } \\
\text { Proses } \\
\text { Cetak nota } \\
\text { "cetak } \\
\quad \text { printer?" ke }\end{array}$ & $\begin{array}{l}\text { Data disimpan } \\
\text { dan } \\
\text { dikosongkan } \\
\text { Hasil Tidak } \\
\quad \text { Keluar } \\
\text { Tidak } \\
\quad \text { Tersimpan }\end{array}$ & Tidak Sesuai \\
\hline
\end{tabular}

Tabel 4. Pengujian FungsionalPembantu Kas

\begin{tabular}{|c|c|c|c|c|}
\hline Test Case & Input Data & Target & Output Nyata & Sesuai \\
\hline 1 & $\begin{array}{l}\text { Nomor transaksi: T- } \\
\quad 0013 \\
\text { Keterangan: } \\
\quad \text { angsuran } \\
\text { Masuk : } 0 \\
\text { Kredit: } 150000 \\
\text { Tgl transaksi: } \\
\quad 11 / 3 / 2015\end{array}$ & $\begin{array}{l}\text { Hasil } \\
\text { Proses } \\
\text { Data tersimpan }\end{array}$ & $\begin{array}{l}\text { Data Dikosongkan } \\
\quad \text { Berhasil } \\
\text { Hasil Tidak Keluar } \\
\text { Tidak Tersimpan }\end{array}$ & Tidak Sesuai \\
\hline
\end{tabular}

\subsection{Kelayakan}

Sistem yang diuji akan menghasilkan informasi data barang, customer, hasil penjualan kredit, pembantu kas. Dari proses yang lain diberikan satu form proses pendataan tersendiri sesuai kebutuhan proses penjualan barang secara kredit dan dianggap layak jika proses tersimpan dengan lengkap. Kelebihan sistem :

1. Hasil proses mudah dipelajari dan dimengerti.

2. Data customer dan piutang bisa tersimpan dengan mudah.

3. Database bisa tertata dan data bisa terbaca dengan cepat

4. Bisa digunakan lebih dari 2 komputer (Multi user)

Kelemahan sistem :

1. Jika data terlalu banyak proses berjalan lambat.

2. Backup data hanya dari sql server saja. 


\section{KESIMPULAN DAN SARAN}

\subsection{Kesimpulan}

Seperti pada tujuan semula yaitu pembuatan aplikasi penjualan kredit secara multiuser maka dapat disimpulkan sebagai berikut :

1. Dalam transaksi perhitungan administrasi angsuran dan pelunasan sudah tertata dengan baik dan dapat diaplikasikan dengan lebih baik.

2. Selain itu, pencarian data mengalami error data karena terlalu banyaknya pelanggan yang sering terlambat mengangsur sudah bisa diselesaikan dengan penataan angsuran dengan database yang lebih baik.

3. Keseluruhan program yang akan dikendalikan oleh sebuah menu utama dan dari semua program ini bisa dioperasikan atau dijalankan oleh orang banyak dengan tingkatan user tersendiri. Proses yang ada terdapat data barang, customer, suplier, kasir,dep barang, transaksi berisi data transaksi pembelian, retur pembelian, penjualan kredit, retur penjualan, pembantu kas. Laporan yang dihasilkan adalah laporan data barang, laporan customer, laporan suplier, laporan departemen barang, laporan transaksi pembelian, laporan retur pembelian, laporan penjualan kredit, laporan retur penjualan, dan laporan pembantu kas.

\subsection{Saran}

Saran yang diberikan adalah sebagai berikut :

1. Sistem informasi yang komputer sebagai alat bantu untuk pengolahan data administrasi dengan menggunakan barcode sistem.

2. Menggunakan sistem penjualan online dan sistem penjualan kredit.

3. Menggunakan sistem delivery (antar barang).

\section{DAFTAR PUSTAKA.}

Muhammad Salahuddin, A. R. (2011). Rekayasa Perangkat Lunak:Terstruktur dan Berorientasi Objek. Bandung: Modula.

Rivai, V. D. (2013). Manajemen Perkreditan Cara Mudah Menganalisis Kredit. Jakarta: PT. Raja Grafindo Persada.

Sutabri.T. (2012). Konsep Sistem Informasi. Yogyakarta: Andi.

Wahana, K. (2010). Panduan Belajar SQL Server. Jakarta: Mediakita. 